\title{
OPINIA RODZICÓW NA TEMAT ODMOWY WYKONANIA SZCZEPIEŃ OCHRONNYCH U DZIECI
}

\author{
PARENTS' OPINION ON THE REFUSAL OF CHILDHOOD VACCINES \\ Katarzyna Szymoniak ${ }^{1, a}$, Daria Cholewa², Dorota Fryc ${ }^{1, b}$, Dorota Ćwiek ${ }^{1, c}$ \\ ${ }^{1}$ Samodzielna Pracownia Umiejętności Położniczych, Wydział Nauk o Zdrowiu, Pomorski Uniwersytet Medyczny w Szczecinie \\ ${ }^{2}$ Samodzielny Publiczny Specjalistyczny Zakład Opieki Zdrowotnej "Zdroje” w Szczecinie \\ ${ }^{\text {a }}$ https://orcid.org/0000-0003-3941-7340 \\ ${ }^{b}$ https://orcid.org/0000-0002-9014-7510 \\ ${ }^{c}$ https://orcid.org/0000-0002-4908-9056
}

DOI: https://doi.org/10.20883/pielpol.2020.18

\section{STRESZCZENIE}

Wstęp. Szczepienia ochronne są najbardziej skutecznym oraz najtańszym sposobem zwalczania oraz zapobiegania chorobom zakaźnym. Uniemożliwiają rozwój powikłań oraz ograniczają rozprzestrzenianie się infekcji. Na przestrzeni lat obserwuje się znaczny rozwój i wzrost profilaktyki chorób poprzez wprowadzanie programów ochronnych szczepień - zalecanych oraz obowiązkowych.

Cel. Celem pracy było poznanie opinii rodziców na temat odmowy wykonania szczepień ochronnych u dzieci.

Materiał i metody. Badaniem objęto 100 pacjentów oddziału położniczego w SSZOZ „Zdroje” w Szczecinie. Do badań wykorzystano autorską ankietę, z zastosowaniem sondażu diagnostycznego. Wyniki badań wykonano za pomocą programu R, wersja 3.4.3. R Core Team (2017).

Wyniki. Spośród 100 respondentów jedynie 12,0\% uważało, że szczepienia ochronne wykonywane u dzieci nie są potrzebne. Wykazano, że 32,0\% rodziców nie zapoznało się w ogóle z obowiązującym kalendarzem szczepień. Większa część respondentów nie wykonuje dodatkowych, zalecanych szczepień u swoich dzieci $(61,0 \%)$. Ponad połowa badanych $(60,0 \%)$ obawia się szczepień ochronnych. Nieco więcej niż połowa ankietowanych rezygnuje ze szczepień refundowanych i kupuje szczepionki (52,0\%). Jednym z głównych źródeł wiedzy rodziców na temat szczepień ochronnych jest lekarz, pielęgniarka, położna oraz Internet (po 81,0\%). Większa część ankietowanych (53,0\%) uważała, iż powinno się nanieść kary na opiekunów, którzy nie szczepią swoich dzieci.

Wnioski. 1) Poziom wiedzy rodziców na temat chorób zakaźnych oraz zasadności wykonywania szczepień ochronnych u dzieci ulega pogorszeniu z uwagi na wpływ nierzetelnych źródeł informacji. 2) Ważnym źródłem wiedzy na temat szczepień jest Internet, 3) Wskazane jest zintensyfikowanie i ukierunkowanie działań pracowników ochrony zdrowia w dysponowaniu rzetelną oraz wiarygodną wiedzą na temat szczepień ochronnych przekazywaną rodzicom.

SŁOWA KLUCZOWE: szczepienia ochronne, dziecko, odmowa.

\section{ABSTRACT}

Introduction. Preventive vaccinations are the most effective and the cheapest method of fighting and preventing infectious diseases. They preclude the development of complications and limit the spread of infections. Over the years, there has been a significant development and growth in disease prevention due to the implementation of preventive vaccination plans, both recommended and compulsory.

Aim. The aim of the study was to examine parents' opinions on the refusal of preventive childhood vaccines.

Material and methods. The study covered 100 patients of the obstetric ward at the Independent Public Complex of Healthcare Facilities 'Zdroje' in Szczecin. The diagnostic survey method in the form of authors' self-designed questionnaire was used in the study. The results were prepared using the $\mathrm{R}$ program, version 3.4.3. R Core Team (2017).

Results. Among 100 respondents, only $12.0 \%$ think that preventive vaccinations of children are unnecessary. The study shows that $32.0 \%$ of parents are not familiar with the obligatory vaccination calendar. Most respondents do not carry out any additional recommended vaccinations on their children $(61.0 \%)$. More than half of the respondents $(60.0 \%)$ are afraid of preventive vaccinations. A slight majority of the respondents buy vaccines instead of using the reimbursed vaccinations $(52.0 \%)$. The main sources of parents' knowledge on the issue of preventive vaccinations are doctors, nurses, midwives and the Internet ( $81.0 \%$ each). Most respondents $(53.0 \%)$ think that there should be penalties for guardians who do not vaccinate their children.

Conclusions. 1) The level of parents' knowledge on infectious diseases and the rationale of vaccinating children is deteriorating due to the influence of unreliable sources of information, 2) The Internet is an important source of knowledge on the issue of vaccinations, 3) It is advisable to intensify and concentrate the efforts of healthcare professionals in having reliable and accurate knowledge on preventive vaccinations that they convey to parents.

KEYWORDS: preventive vaccinations, child, refusal. 


\section{Wprowadzenie}

Szczepienia ochronne są najskuteczniejszym sposobem zapobiegania chorobom zakaźnym. Ograniczają rozprzestrzenianie się infekcji oraz zapobiegają powikłaniom (śmiertelnym także). Systematyczne szczepienie jednostek w społeczeństwie prowadzi do odporności całej ludności, idąc dalej może nawet doprowadzić do całkowitego zwalczenia choroby [1]. Na przestrzeni lat obserwuje się znaczny wzrost i rozwój profilaktyki chorób zakaźnych poprzez wprowadzanie programów szczepień ochronnych - zalecanych oraz obowiązkowych.

Temat badań jest bardzo aktualny i dość kontrowersyjny z punktu widzenia społeczeństwa, wywołujący intensywne emocje. W pracy przedstawiono zmiany, jakie zaszły w ostatnim czasie w świadomości osób biorących udział w cyklu szczepień ochronnych u dzieci. Dotyczyły one podejścia do problemu szczepień ochronnych i jego zasadności. Osoby opiekujące się dziećmi chcą mieć większy wpływ na decyzję o przystąpieniu do programu szczepień. Edukacja w tym zakresie, kształtująca i modyfikująca przekonania rodziców, uzależniona jest od szybkiego wyjaśniania obaw i niedomówień przy stosowaniu programu szczepień ochronnych (PSO).

\section{Cel pracy}

Celem pracy było poznanie opinii rodziców na temat odmowy wykonania szczepień ochronnych u dzieci.

\section{Materiał i metody}

W badaniu wzięło udział 100 rodziców (matki i ojcowie) przebywających z dziećmi na oddziale położniczym w SPSZOZ „Zdroje” w Szczecinie. Ankietowanych uprzedzono o celowości i anonimowości badania oraz uzyskano zgodę. Badania zostały przeprowadzone w oparciu o ankietę własnego autorstwa. Kwestionariusz składał się z 25 pytań, w tym pytania do pozyskania danych socjodemograficznych.

Prowadzone badania nie wymagały zgody komisji bioetycznej. Analizę statystyczną pozyskanych danych przeprowadzono za pomocą testu chi-kwadrat (z korektą Yatesa dla tabel 2x2) lub dokładnego testu Fishera tam, gdzie w tabelach pojawiały się niskie liczności oczekiwane. W analizie przyjęto poziom istotności $\mathrm{p}<0,05$. Analizy statystyczne wykonano w programie R, wersja 3.4.3. R Core Team (2017).

\section{Wyniki}

Analiza danych socjodemograficznych wykazała, że znaczną część osób badanych stanowiły kobiety (93,0\%), natomiast 7,0\% ankietowanych było płci męskiej. Najwięcej respondentów było w przedziale wie- kowym od 26. do 30. roku życia (33,0\%), następnie od 31. do 40. roku życia, najmniej respondentów było w przedziale od 18. do 25. roku życia (14,0\%). Najczęstszym wykształceniem rodziców było wykształcenie wyższe oraz średnie (po 35,0\%), następnie wykształcenie zawodowe (16,0\%) i podstawowe (11,0\%), trzech ankietowanych nie udzieliło odpowiedzi na to pytanie. Ponad połowa respondentów była w związku małżeńskim (56,0\%), w związku partnerskim było 37,0\% osób, natomiast najmniej ankietowanych było stanu wolnego $(6,0 \%)$. Najwięcej badanych zamieszkiwało miasta (68,0\%). Analizując status majątkowy respondentów, większość oceniła swój status jako średni (57,0\%), jako dobry oceniło $40,0 \%$ osób, natomiast najmniej badanych wskazało zły status (2,0\%), 1 ankietowany nie udzielił odpowiedzi na to pytanie.

Rodziców zapytano o potrzebę wykonywania szczepień ochronnych u dzieci. Większa część uważała, że szczepienia ochronne u dzieci są potrzebne (87,0\%).

Argumentacją osób uważających, że szczepienia są potrzebne było: szczepienia chronią przed chorobami; uodparniają; chronią i zapobiegają powikłaniom; szczepienia wyeliminowały groźne choroby oraz powstrzymują epidemie chorób. Osoby uważające szczepienia za zbędne argumentowały to następująco: szczepienia nie są potrzebne, skoro takich chorób już nie ma; dziecko samo się uodporni; lepiej by dziecko przeszło chorobę samo, niż zostało sztucznie zaszczepione; groźne powikłania poszczepienne; szczepionki są przyczyną chorób dzieci oraz szczepienia to sama chemia i szkodliwe substancje (np. rtęć).

Respondentów zapytano również, czy znają aktualny kalendarz szczepień ochronnych. Większa część badanych udzieliła odpowiedzi twierdzącej (67,0\%).

Kolejne pytanie dotyczyło struktury wykonywania szczepień ochronnych u starszych dzieci zgodnie z kalendarzem szczepień. Większość rodziców $(76,0 \%)$ potwierdzało wykonywanie szczepień zgodnie z kalendarzem, natomiast aż 23,0\% respondentów nie robiło tego. Przyczyny odmowy wykonania u dzieci szczepień ochronnych zgodnie z kalendarzem były następujące: niewiara w celowość i skuteczność szczepionek; szczepienia odroczone do tego czasu, aby mieć pewność, że dziecko jest całkowicie zdrowe; wiara w uodpornienie organizmu dziecka bez konieczności szczepienia.

Kolejnym krokiem pracy było zbadanie obaw rodziców dotyczących szczepienia dziecka. Ponad połowa respondentów $(60,0 \%)$ stwierdziła, że szczepienia stanowią dla nich problem. Natomiast $39,0 \%$ odpowiedziało, że nie obawia się szczepień ochronnych. Najczęściej rodzice obawiali się: powikłań poszczepiennych (92,0\%), niebezpiecznego składu szczepionki (35,0\%), 
bólu i stresu dla dziecka (48,0\%) oraz innych powikłań (50,0\%).

Tabela 1. Wiek, wykształcenie i stan cywilny a obawa rodziców przed szczepieniem dziecka

Table 1. Age, education and marital status versus parents' concern about children vaccinations

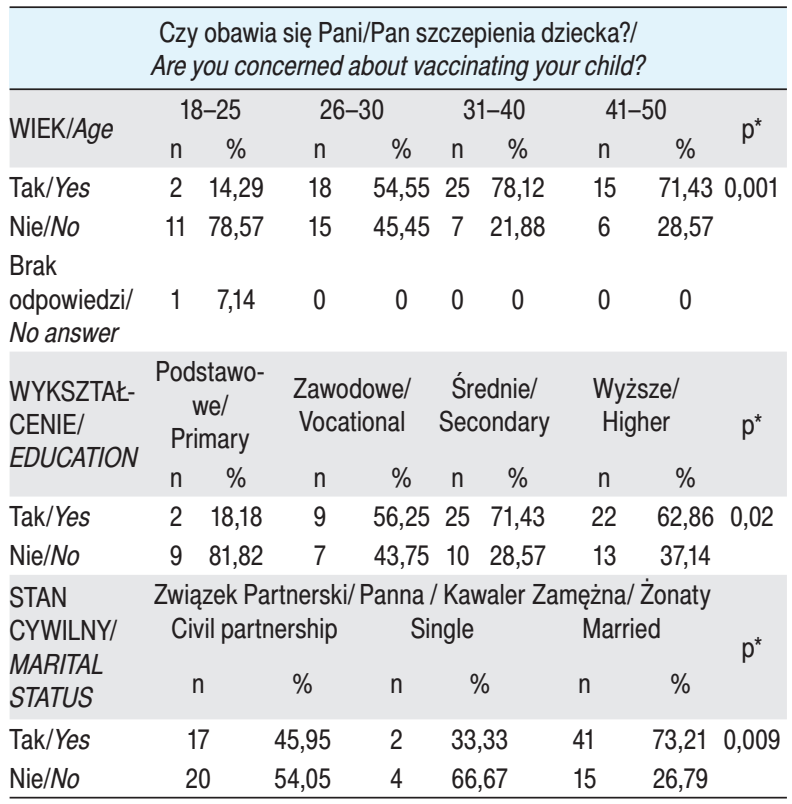

Źródło: opracowanie własne

Source: author's own analysis

Analizując zależność pomiędzy wiekiem, wykształceniem i stanem cywilnym respondentów a obawą przed szczepieniem dziecka, wykazano różnice istotne statystycznie. Rodzice po 30. roku życia $(0,001)$, o wykształceniu średnim, wyższym i zawodowym $(0,02)$ oraz będący w związkach małżeńskich $(0,009)$ istotnie częściej obawiali się wykonywania szczepień ochronnych u swoich dzieci (Tabela 1).

Zbadano, czy ankietowani wykonują zalecane, dodatkowe, płatne szczepienia przeciwko innym chorobom u swoich dzieci. Większa część respondentów (61,0\%) nie wykonywała dodatkowych szczepień, natomiast $38,0 \%$ osób poddało dzieci tym szczepieniom. Rodzice za przyczyny odmowy wykonania szczepień zalecanych podawali m.in.: zbyt wysoką cenę; brak wiary w skuteczność szczepień; obawę przed wystąpieniem NOP; małą ilość wiedzy na temat zalecanych szczepień; obawę przed kolejnymi iniekcjami u dziecka. Ankietowani, którzy deklarowali zaszczepienie dzieci szczepionkami zalecanymi, argumentowali swoje wypowiedzi m.in.: dodatkową ochroną dziecka przed chorobami zakaźnymi; sugestią lekarza; lepszym uodpornieniem dziecka.
Tabela 2. Rodzaje wykonywanych zalecanych, dodatkowych, nieobowiązkowych oraz płatnych szczepień u dzieci

Table 2. Types of recommended, additional, voluntary and paid vaccinations carried out on children

\begin{tabular}{lcc}
\hline $\begin{array}{l}\text { Rodzaje wykonywanych zalecanych, dodatkowych, } \\
\text { nieobowiązkowych oraz płatnych szczepień u dzieci/ } \\
\begin{array}{c}\text { Types of recommended, additional, voluntary and paid } \\
\text { vaccinations carried out on children }\end{array}\end{array}$ & $\mathrm{n}^{*}$ & $\%^{*}$ \\
\hline Przeciw meningokokom/Meningococcal vaccines & 23 & 61,0 \\
\hline $\begin{array}{l}\text { Przeciw kleszczowemu zapaleniu mózgu/Tick-borne } \\
\text { Encephalitis vaccines }\end{array}$ & 0 & 0 \\
\hline Przeciw rotawirusom/Rotavirus vaccines & 18 & 47,0 \\
\hline Przeciw ospie wietrznej/Varicella vaccines & 0 & 0 \\
\hline Przeciw grypie/lnfluenza vaccines & 8 & 21,0 \\
\hline Inne/Other & 11 & 29,0 \\
\hline
\end{tabular}

* Odsetki nie sumują się do 100\%, gdyż było to pytanie wielokrotnego wyboru. / * Numbers do not sum up to $100 \%$ as it was a multi-choice question.

Źródło: opracowanie własne

Source: author's own analysis

Spośród 38,0\% osób, które wykonały dodatkowe, płatne szczepienia ochronne, najwięcej wskazało szczepienie przeciw meningokokom, przeciwko rotawirusom oraz szczepienie przeciwko grypie (odpowiednio $61,0 \%, 47,0 \%$ i $21,0 \%$ ), kolejne $29,0 \%$ ankietowanych wskazało „inne” szczepienia (Tabela 2).

Rodziców zapytano również, czy wykonaliby u swoich dzieci dodatkowe, zalecane szczepienia, gdyby były bezpłatne. Za wykonaniem darmowych, zalecanych szczepień była ponad połowa ankietowanych $(66,0 \%)$.

Tabela 3. Źródła wiedzy rodziców na temat szczepień ochronnych u dzieci

Table 3. Sources of parents' knowledge on preventive children vaccinations

\begin{tabular}{lccc}
\hline $\begin{array}{l}\text { Co było źródłem wiedzy Pani/Pana na temat szczepień } \\
\text { ochronnych u dzieci?/What was your source of know- }\end{array}$ & $\mathrm{n}^{*}$ & $\%$ * \\
ledge on the topic of preventive children vaccinations? & & \\
\hline Lekarz, pielęgniarka, położna/Doctors, nurses, midwives & 81 & 81,0 \\
\hline Internet/The Internet & 81 & 81,0 \\
\hline Inni rodzice/Other parents & 66 & 66,0 \\
\hline Literatura medyczna/Medical literature & 41 & 41,0 \\
\hline Telewizja/Television & 4 & 4,0 \\
\hline Inne/Other & 15 & 15,0 \\
\hline
\end{tabular}

* Odsetki nie sumują się do $100 \%$, gdyż było to pytanie wielokrotnego wyboru.

* Numbers do not sum up to $100 \%$ as it was a multi-choice question.

Źródło: opracowanie własne

Source: author's own analysis 
Wśród rodziców analizowano także źródła wiedzy na temat ochronnych szczepień u dzieci (możliwość wielokrotnej odpowiedzi). Wykazano, iż 81,0\% badanych wskazało na lekarza, pielęgniarkę i położną lub Internet. Następnie 66,0\% osób jako źródło swojej wiedzy wskazało opinie innych rodziców, dalej literaturę medyczną (41,0\%) (Tabela 3).

Tabela 4. Wiek i stan cywilny badanych a źródła wiedzy na temat szczepień ochronnych u dzieci

Table 4. Age and marital status of the respondents versus sources of knowledge on preventive children vaccinations

\begin{tabular}{|c|c|c|c|c|c|c|c|c|}
\hline \multicolumn{9}{|c|}{$\begin{array}{l}\text { Co jest źródłem wiedzy Pani/Pana na temat szczepień ochronnych u dzieci?/ } \\
\text { What is your source of knowledge on the topic of preventive children vacci- } \\
\text { nations? }\end{array}$} \\
\hline \multirow[b]{2}{*}{ WIEK/Age } & \multicolumn{2}{|c|}{$18-25$} & \multicolumn{2}{|c|}{$26-30$} & $31-40$ & \multicolumn{2}{|c|}{$41-50$} & \multirow{2}{*}{$p^{* *}$} \\
\hline & $\mathrm{n}^{*}$ & $\%^{*}$ & $n^{*}$ & $\%^{*}$ & $n^{*} \quad \%^{*}$ & $n^{*}$ & $\%^{*}$ & \\
\hline $\begin{array}{l}\text { Lekarz, pie- } \\
\text { lęgniarka, } \\
\text { położna/ } \\
\text { Doctors, } \\
\text { nurses, } \\
\text { midwives }\end{array}$ & 8 & 57,14 & 24 & 72,73 & 3093,75 & 19 & 90,48 & $0,009 \mathrm{~F}$ \\
\hline $\begin{array}{l}\text { Internet/The } \\
\text { Internet }\end{array}$ & 12 & 85,71 & 28 & 84,85 & 2578,12 & 16 & 76,19 & $0,81 \mathrm{~F}$ \\
\hline $\begin{array}{l}\text { Inni rodzice/ } \\
\text { Other } \\
\text { parents }\end{array}$ & 9 & 64,29 & 23 & 69,70 & 2268,75 & 12 & 57,14 & $0,795 \mathrm{~F}$ \\
\hline $\begin{array}{l}\text { Literatura } \\
\text { medyczna/ } \\
\text { Medical } \\
\text { literature }\end{array}$ & 4 & 28,57 & 12 & 36,36 & 1237,50 & 13 & 61,90 & 0,162 \\
\hline $\begin{array}{l}\text { Telewizja/ } \\
\text { Television }\end{array}$ & 0 & 0 & 0 & 0 & $\begin{array}{ll}3 & 9,38\end{array}$ & 1 & 4,76 & $0,28 \mathrm{~F}$ \\
\hline Inne/Other & 3 & 21,43 & 4 & 12,12 & $7 \quad 21,88$ & 1 & 4,76 & $0,304 \mathrm{~F}$ \\
\hline \multirow{2}{*}{$\begin{array}{l}\text { STAN } \\
\text { CYWILNY/ } \\
\text { MARITAL } \\
\text { STATUS }\end{array}$} & \multicolumn{3}{|c|}{$\begin{array}{r}\text { Związek partnersk } \\
\text { Civil partnership }\end{array}$} & $\begin{array}{r}\text { Panna/ } \\
\text { Sin }\end{array}$ & $\begin{array}{l}\text { Kawaler Z } \\
\text { gle }\end{array}$ & $\begin{array}{r}\text { amężnz } \\
\text { Mar }\end{array}$ & /Żonaty & \multirow[t]{2}{*}{$p^{* *}$} \\
\hline & $n^{*}$ & & & $n^{*}$ & $\%^{*}$ & $n^{*}$ & $\%^{*}$ & \\
\hline $\begin{array}{l}\text { Lekarz, pie- } \\
\text { lęgniarka, } \\
\text { położna/ } \\
\text { Doctors, } \\
\text { nurses, } \\
\text { midwives }\end{array}$ & 25 & & 57 & 6 & 100,0 & 50 & 89,29 & 0,024 \\
\hline $\begin{array}{l}\text { Internet/The } \\
\text { Internet }\end{array}$ & 34 & & 89 & 3 & 50,0 & 44 & $78,57 \%$ & 0,033 \\
\hline $\begin{array}{l}\text { Inni rodzice/ } \\
\text { Other } \\
\text { parents }\end{array}$ & 28 & & & 1 & 16,67 & 37 & 66,07 & 0,018 \\
\hline $\begin{array}{l}\text { Literatura } \\
\text { medyczna/ } \\
\text { Medical } \\
\text { literature }\end{array}$ & 10 & & & 2 & 33,33 & 29 & 51,79 & 0,05 \\
\hline $\begin{array}{l}\text { Telewizja/ } \\
\text { Television }\end{array}$ & 0 & & & 0 & 0 & 4 & 7,14 & 0,339 \\
\hline Inne/Other & 6 & & 22 & 0 & 0 & 9 & 16,07 & 0,816 \\
\hline
\end{tabular}

* Odsetki nie sumują się do $100 \%$, gdyż było to pytanie wielokrotnego wyboru. /*Numbers do not sum up to $100 \%$ as it was a multi-choice question/ ${ }^{*}$ Dokładny test Fishera (niskie wartości oczekiwane w tabeli)/ ** Exact Fisher's test (low values expected in the table).

Źródło: opracowanie własne

Source: author's own analysis
Analizując zależność pomiędzy wiekiem i stanem cywilnym respondentów a wyborem źródła wiedzy na temat szczepień ochronnych, wykazano istotność statystyczną. Rodzice po 30. roku życia $(0,009)$, będący w związkach małżeńskich, jak i samotnie wychowujący dzieci $(0,02)$ istotnie częściej wskazywali, że ich podstawowym źródłem wiedzy był lekarz, pielęgniarka, położna. Natomiast respondenci poniżej 30. roku życia, będący w związkach partnerskich wskazywali na Internet jako podstawowe źródło wiedzy (Tabela 4).

Tabela 5. Poziom wiedzy na temat szczepień obowiązkowych przeciwko chorobom zakaźnym w opinii badanych Table 5. Respondents' level of knowledge on compulsory vaccinations against infectious diseases, according to their own estimation

Jak ocenia Pani/Pan swój poziom wiedzy na temat chorób zakaźnych, przeciwko którym szczepione są dzieci? (Krztusiec, Błonica, Tężec, Odra, Świnka, Różyczka, Hib, Polio, Pneumokoki, Gruźlica, WZW B)/How would you rate your level of knowledge on infectious diseases that children are vaccinated against? (whooping cough, diphteria, tetanus, measles, mumps, rubella, Hib, polio, pneumococcus, tuberculosis, hepatitis $B$ )

\begin{tabular}{lll}
\hline Wysoki/High & 12 & 12 \\
\hline Zadowalający/Satisfactory & 52 & 52 \\
\hline Niski/Low & 18 & 18 \\
Brak wiedzy/None & 0 & 0 \\
\hline Trudno powiedzieć/Difficult to say & 16 & 16 \\
Brak odpowiedzi/No answer & 2 & 2 \\
\hline
\end{tabular}

Źródło: opracowanie własne

Source: author's own analysis

Analiza poziomu wiedzy respondentów na temat ochronnych szczepień przeciwko chorobom zakaźnym wykazała, że większość rodziców określiło swój poziom wiedzy na poziomie zadowalającym (52,0\%), następnie na poziomie niskim (18,0\%), kolejno „trudno powiedzieć” $(16,0 \%)$ oraz na wysokim poziomie $(12,0 \%)$ (Tabela 5).

Tabela 6. Wiek i wykształcenie a poziom wiedzy na temat szczepień ochronnych u dzieci w opinii badanych

Table 6. Age and education versus respondents' level of knowledge on preventive children vaccinations, according to their own estimation.n

\begin{tabular}{|c|c|c|c|c|c|c|c|c|c|}
\hline \multicolumn{10}{|c|}{$\begin{array}{c}\text { Jak ocenia Pani/Pan swój poziom wiedzy na temat chorób zakaźnych, } \\
\text { przeciwko którym szczepione są dzieci? (Krztusiec, błonica, tężec, odra, } \\
\text { świnka, różyczka, gruźlica, WZW B)/How would you rate your level of } \\
\text { knowledge on infectious diseases that children are vaccinated against? } \\
\text { (whooping cough, diphteria, tetanus, measles, mumps, rubella, tuberculo- } \\
\text { sis, hepatitis B) }\end{array}$} \\
\hline \multirow{2}{*}{ WIEK/Age } & \multicolumn{2}{|c|}{$18-25$} & \multicolumn{2}{|c|}{$26-30$} & \multicolumn{2}{|c|}{$31-40$} & \multicolumn{2}{|c|}{$41-50$} & \multirow{2}{*}{$p^{*}$} \\
\hline & $\mathrm{n}$ & $\%$ & $\mathrm{n}$ & $\%$ & $\mathrm{n}$ & $\%$ & 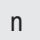 & $\%$ & \\
\hline Nysoki/High & 0 & 0 & 2 & 6,06 & 5 & 15,62 & 5 & 23,81 & 0,002 \\
\hline $\begin{array}{l}\text { adowalający/ } \\
\text { atisfactory }\end{array}$ & 4 & 28,57 & 15 & 45,45 & 19 & 59,38 & 14 & 66,67 & \\
\hline liski/Low & 7 & 50,0 & 7 & 21,21 & 3 & 9,38 & 1 & 4,76 & \\
\hline
\end{tabular}




\begin{tabular}{|c|c|c|c|c|c|c|c|c|c|}
\hline $\begin{array}{l}\text { Brak wiedzy/ } \\
\text { None }\end{array}$ & 0 & 0 & 0 & 0 & 0 & 0 & 0 & 0 & \\
\hline $\begin{array}{l}\text { Trudno powie- } \\
\text { dzieć/Diffcult } \\
\text { to say }\end{array}$ & 1 & 7,14 & 9 & 27,27 & 5 & 15,62 & 1 & 4,76 & \\
\hline $\begin{array}{l}\text { Brak odpowie- } \\
\text { dzi/No answer }\end{array}$ & 2 & 14,29 & 0 & 0 & 0 & 0 & 0 & 0 & \\
\hline \multirow{2}{*}{$\begin{array}{l}\text { WYKSZTAt- } \\
\text { CENIE }\end{array}$} & \multicolumn{2}{|c|}{$\begin{array}{c}\text { Podstawowe/ } \\
\text { Primary }\end{array}$} & \multicolumn{2}{|c|}{$\begin{array}{l}\text { Zawodowe/ } \\
\text { Vocational }\end{array}$} & \multicolumn{2}{|c|}{$\begin{array}{l}\text { Średnie/ } \\
\text { Secondery }\end{array}$} & \multicolumn{2}{|c|}{$\begin{array}{c}\text { Wyższe/ } \\
\text { Higher }\end{array}$} & $\mathrm{p}^{*}$ \\
\hline & $n$ & $\%$ & $\mathrm{n}$ & $\%$ & $n$ & $\%$ & $\mathrm{n}$ & $\%$ & \\
\hline Wysoki/High & 0 & 0 & 1 & 6,25 & 4 & 11,43 & 6 & 17,14 & 0,001 \\
\hline $\begin{array}{l}\text { Zadowalający/ } \\
\text { Satisfactory }\end{array}$ & 1 & 9,09 & 9 & 56,25 & 17 & 48,57 & 24 & 68,57 & \\
\hline Niski/Low & 7 & 63,64 & 2 & 12,50 & 7 & 20,0 & 2 & 5,71 & \\
\hline $\begin{array}{l}\text { Brak wiedzy/ } \\
\text { None }\end{array}$ & 0 & 0 & 0 & 0 & 0 & 0 & 0 & 0 & \\
\hline $\begin{array}{l}\text { Trudno powie- } \\
\text { dzié́/Diffcult } \\
\text { to say }\end{array}$ & 2 & 18,18 & 4 & 25,0 & 7 & 20,0 & 3 & 8,57 & \\
\hline $\begin{array}{l}\text { Brak odpowie- } \\
\text { dzi/No answer }\end{array}$ & 1 & 9,09 & 0 & 0 & 0 & 0 & 0 & 0 & \\
\hline
\end{tabular}

Źródło: opracowanie własne

Source: author's own analysis

Dokonując analizy zależności pomiędzy wiekiem i wykształceniem respondentów a poziomem ich wiedzy na temat szczepień ochronnych, wykazano istotność statystyczną. Rodzice po 26. roku życia $(0,002)$, z wykształceniem wyższym, zawodowym i średnim $(0,001)$ istotnie częściej wskazywali, że ich poziom wiedzy na temat szczepień jest zadowalający. Wraz ze wzrostem wykształcenia i wieku rośnie poziom wiedzy (Tabela 6).

Ankietowanych zapytano również, czy ich zdaniem powinno się nakładać kary na rodziców, którzy odmawiają wykonania obowiązkowych szczepień u swoich dzieci. Spośród 100 respondentów większa część (53,0\%) badanych była zdania, iż powinno się karać rodziców, którzy nie wykonują obowiązkowych szczepień. Natomiast 46,0\% uważała, że karanie tych osób jest niepotrzebne. Jedna osoba wstrzymała się od odpowiedzi $(1,0 \%)$.

Tabela 7. Wykształcenie a kara za odmowę wykonania obowiązkowych szczepień ochronnych

Table 7. Education versus penalty for refusing to carry out compulsory preventive vaccinations

\begin{tabular}{|c|c|c|c|c|c|c|c|c|c|}
\hline \multicolumn{10}{|c|}{$\begin{array}{c}\text { Czy jest Pani/Pan zdania, że odmowa obowiązkowych szczepień ochronnych } \\
\text { powinna być karana?/Do you think there should be a penalty for refusing } \\
\text { compulsory preventive vaccinations? }\end{array}$} \\
\hline \multirow[t]{2}{*}{$\begin{array}{l}\text { WYKSZTAŁCENIE/ } \\
\text { EDUCATION }\end{array}$} & \multicolumn{2}{|c|}{$\begin{array}{l}\text { Podsta- } \\
\text { wowe/ } \\
\text { Primary }\end{array}$} & \multicolumn{2}{|c|}{$\begin{array}{l}\text { Zawo- } \\
\text { dowe/ } \\
\text { Vocational }\end{array}$} & \multicolumn{2}{|c|}{$\begin{array}{l}\text { Średnie/ } \\
\text { Secondary }\end{array}$} & \multicolumn{2}{|c|}{$\begin{array}{l}\text { Wyższe/ } \\
\text { Higher }\end{array}$} & \multirow[t]{2}{*}{$\mathrm{p}^{*}$} \\
\hline & $n$ & $\%$ & $n$ & $\%$ & $n$ & $\%$ & $n$ & $\%$ & \\
\hline Tak/Yes & 4 & 36,36 & 12 & 75,0 & 22 & 62,86 & 14 & 40,0 & 0,045 \\
\hline Nie/No & 7 & 63,64 & 4 & 25,0 & 13 & 37,14 & 21 & 60,0 & \\
\hline
\end{tabular}

* Test chi-kwadrat/ *Chi-square test

Źródło: opracowanie własne

Source: author's own analysis
Analizując zależność pomiędzy zmiennymi niezależnymi (wiek, miejsce zamieszkania, wykształcenie, stan cywilny) a opinią na temat karania osób uchylających się od wykonywania szczepień ochronnych, wykazano istotność statystyczną dla zmiennej - wykształcenie $(0,045)$. Rodzice z wykształceniem zawodowym i średnim istotnie częściej by karali rodziców nieszczepiących swoich dzieci w przeciwieństwie do respondentów z wykształceniem podstawowym oraz wyższym (Tabela 7).

\section{Dyskusja}

Szczepienia ochronne dały dzieciom na całym świecie znacznie więcej korzyści niż inne preparaty lecznicze czy też interwencje medyczne. Bez cienia wątpliwości pozostają one najtańszą i najskuteczniejszą metodą zapobiegania rozprzestrzenianiu się chorób zakaźnych [2]. Wprowadzenie ochronnych szczepień do profilaktyki zakaźnych chorób stało się ważnym, przełomowym oraz odkrywczym momentem w ich zwalczaniu. Wytyczne dotyczące przeprowadzania ochronnych szczepień, zwane inaczej kalendarzem szczepień, co roku opracowuje i przedstawia Ministerstwo Zdrowia w formie rozporządzenia, które obwiązuje na terenie całego kraju.

Analiza potrzeby wykonywania ochronnych szczepień u dzieci w badaniach własnych wykazała, że $12,0 \%$ ankietowanych było temu przeciwnych. Porównując to z wynikami Łopaty i wsp. [3] odpowiedzi negatywne sięgały nawet $20,0 \%$ respondentów. Opinii tej nie potwierdzają w swoich badaniach Kiełducka i Tarka [4], u których tylko 1,0\% badanych było przeciwnych. Natomiast w pracy Wróblewskiej i wsp. [5] 11,0\% badanych negatywnie zapatrywało się na potrzebę szczepień ochronnych u swoich dzieci.

Analiza badania Gawlik i wsp. [6] wykazała, że rodzice, którzy odmawiali wykonania szczepień u swoich dzieci, jako przyczynę podawali zagrożenie zdrowia dziecka, przede wszystkim w postaci wystąpienia groźnych powikłań, a także, że szczepionki nie są dobrze przebadane. Rodzice również byli zaniepokojeni odczynami poszczepiennymi (26,0\% respondentów). Największe emocje wzbudzała liczba szczepionek aplikowanych dzieciom oraz strach przed zachorowaniem na autyzm oraz nowotwory.

Wśród ankietowanych 32,0\% nie zapoznało się z kalendarzem szczepień na rok 2017. Najczęściej znajomość aktualnego kalendarza szczepień deklarowały osoby w wieku 31-40 lat, a najrzadziej osoby w wieku 18-25 lat. W badaniach Wróblewskiej i wsp. [5] 42,0\% ankietowanych nie interesowało się aktualnym kalendarzem szczepień, natomiast znajomość kalendarza deklarowała tylko połowa $(49,0 \%)$ osób w wieku 26-35 lat. W przypadku badań Faleńczyka iwsp. [7] wskazano, że ok. 33,0\% rodziców nie sprawdza- 
ło harmonogramu szczepień. Podobne wyniki uzyskano w badaniach własnych. Dla wielu rodziców wezwanie z punktu szczepień jest skuteczną metodą realizowania szczepień ochronnych w terminie. Z tej przyczyny olbrzymia odpowiedzialność spoczywa na pracownikach ochrony zdrowia, gdyż stanowią oni podstawowe źródło informacji dla rodziców.

W badaniach własnych wykazano iż, 39,0\% ankietowanych obawiało się szczepienia swojego dziecka. W badaniach Kiełduckiej i Tarki [4] stwierdzono, że $77,0 \%$ ma obawy dotyczące szczepienia dziecka. Dla $66,0 \%$ osób również ból i stres dziecka związany z iniekcją ma ogromny wpływ na obawy rodziców dotyczące szczepień. W badaniach własnych $29,0 \%$ osób wyraziło tym tematem niepokój. Uwzględniając wykształcenie respondentów w badaniach własnych najbardziej szczepień obawiały się osoby z wykształceniem średnim, a najmniej osoby z wykształceniem podstawowym. Analizując badania Pieszki i wsp. [8] stwierdzono, że im wyższe wykształcenie, tym częstsze obawy dotyczące szczepień.

W badaniach własnych wykazano, że 66,0\% respondentów było zainteresowanych dodatkowymi, zalecanymi, darmowymi szczepieniami ochronnymi. Autorzy publikacji dotyczących tematyki szczepień wskazują, że istnieje niedostatek informacji od rodziców na temat szczepień zalecanych. Badania Wróblewskiej i wsp. [5] wykazały, że decyzje rodziców o immunizacji są podejmowane coraz częściej, ale jest to zależne od sytuacji materialnej rodziny. Potwierdzają to badania własne. Ponadto Kiełducka i Tarka [4] stwierdziły, że 92,0\% rodziców skorzystałoby z bezpłatnych szczepień zalecanych.

Analizujac badania Kuchar i Szenborn [9], zauważono zbieżność z badaniami własnymi. Autorzy przedstawiają, że prawie połowa rodziców rezygnuje ze szczepionek refundowanych na rzecz płatnych, kierując się informacjami o rzekomej mniejszej toksyczności dla organizmu dziecka. Również sugestia o „lepszym”, mniej inwazyjnym działaniu na układ immunologiczny dziecka powodowała chęć rodziców do zamiany szczepionki. W badaniach własnych wykazano, iż 52,0\% ankietowanych szczepi swoje dzieci szczepionkami płatnymi i rezygnuje z refundowanych. Ponadto $56,0 \%$ rodziców uważało, że szczepionki wieloskładnikowe to dobre rozwiązanie. Potwierdza to w swojej pracy Kuchar i Szenborn [9], u których rodzice trudno akceptowali wielokrotne iniekcje u dzieci. W artykule Pieszki i wsp. [8] również rodzice kierowali się „większą skutecznością i bezpieczeństwem oraz nowoczesnością" wybierając płatne, skojarzone szczepionki (45,6\%). Najważniejszym czynnikiem dla ankietowanych było ograniczenie liczby wkłuć $(89,9 \%)$, a więc szczepionki płatne, skojarzone wybierało $63,0 \%$ badanych.
Na pytanie o wykonywanie szczepień zalecanych, dodatkowych, nieobowiązkowych oraz płatnych przeciwko innym chorobom 38,0\% respondentów odpowiedziało twierdząco, z czego przeciw meningokokom - 23,0\%, a przeciw rotawirusom - 18,0\% rodziców. W badaniach Rogalskiej i wsp. [10] zauważono, że rodzice mają problem z rozróżnianiem szczepień obowiązkowych i zalecanych. Podejmowane przez rodziców decyzje uzależnione były od zdobytej wiedzy oraz "mody" i jedynie 10,0\% respondentów wskazało szczepienie przeciwko pneumokokom. W opracowaniu Jaroszewskiej i wsp. [11] rodzice najczęściej wybierali pneumokoki $(37,0 \%)$, rotawirusy $(23,0 \%)$ oraz meningokoki. Natomiast głównym źródłem wiedzy na temat szczepień zalecanych był Internet $(64,0 \%)$ i lekarz pediatra (59,0\%). Należy pamiętać, że dzieci urodzone po 1 stycznia 2017 r. są szczepione obowiązkowo szczepionką przeciw pneumokokom - była to ważna zmiana w kalendarzu szczepień na 2017 rok [12].

Badania własne wykazały, że poziom wiedzy rodziców na temat szczepień obowiązkowych u 52,0\% respondentów był zadowalający, a u 12,0\% wysoki. Z badań Kochman i Rudzińskiej [13] wynika, że poziom wiedzy uzależniony jest proporcjonalnie od wykształcenia i miejsca zamieszkania ankietowanych. Jedynie 29,0\% respondentów potrafiło prawidłowo rozróżnić szczepionki obowiązkowe i zalecane. Natomiast 42,0\% wskazywało na znaczny brak informacji w tym temacie. W badaniach Faleńczyka i wsp. [7] autorzy wykazali, że respondenci z wyższym wykształceniem w 45,0\% wskazali poziom wiedzy na temat szczepień jako średni lub duży. Pokrywa się to z wynikami badań własnych. Biorąc pod uwage wykształcenie respondentów - im wyższe wykształcenie, tym lepsza ocena własnej wiedzy. Według Faleńczyka i wsp. [7] wiedzę na niskim poziomie deklarowało $8,0 \%$ badanych. W badaniach własnych była to grupa 18,0\% osób.

Pytanie określające źródła wiedzy na temat szczepień obowiązkowych wykazało, iż Internet, jako podstawowe źródło, dorównuje autorytetowi pracowników ochrony zdrowia. Badania Faleńczyka i wsp. [7] także zrównują wiarygodność obydwu źródeł, zaznaczając, że przewaga zaufania do pracowników ochrony zdrowia jest niewielka wobec Internetu. W badaniu autorzy wykazali, że spośród mediów będących źródłem wiedzy dla rodziców na pierwszym miejscu coraz częściej pojawia się Internet. Uzyskane wyniki są spójne z badaniami prowadzonymi przez ośrodek krakowski, w którym ankietowani również podkreślają ogromną rolę Internetu, jako źródła pozyskiwania informacji na temat szczepień ochronnych. W badaniach własnych wykazano, iż rodzice z wykształceniem podstawowym i średnim jako główne źródło wiedzy podawali Internet, a w dru- 
giej kolejności pracowników ochrony zdrowia, natomiast z wyższym wykształceniem odwrotnie. Według Faleńczyka i wsp. [7] rodzice z wykształceniem podstawowym/zawodowym, jako podstawowe źródło informacji na temat szczepień wymieniali najczęściej rozmowę z pielęgniarką, następnie z lekarzem. Ulotki informacyjne stanowiły 13,8\%. Badani ze średnim wykształceniem wskazywali na ulotki informacyjne, następnie konsultacje z pielęgniarką i lekarzem oraz Internet. Ankietowani z wyższym wykształceniem wskazywali na Internet, ulotki i konsultację z lekarzem jako sposób uzyskiwania informacji.

Analiza opinii na temat nałożenia kary za odmowę wykonania szczepień obowiązkowych wykazała, że poparło ją 53,0\% respondentów. Bazując na materiałach porównawczych, większość respondentów zgodziła się ze stwierdzeniem, że choroby zakaźne są nadal groźne i poprzez szczepienia rodzice dbają o zdrowie swoich dzieci. Wiedza o istniejących niedaleko Europy miejscach endemicznych występowania groźnych wirusów również nie była obca odpowiadającym. Gawlik i wsp. [6] wykazali w swoich badaniach, że 97,0\% odpowiedzi było zgodnych, że choroby zakaźne są nadal groźne. Grupa 54,0\% twierdziła, że szczepienia to jedyna skuteczna obrona przeciwko chorobom zakaźnym. Natomiast $85,0 \%$ badanych twierdziło, że dzięki szczepieniom dbają o swoje dzieci. Takie wysokie wyniki świadczą o akceptowalności szczepień obowiązkowych przez rodziców, pomimo różnych obaw i niepewności sygnalizowanych w wypowiedziach. Tym bardziej dziwi fakt, że aż 46,0\% ankietowanych w badaniach własnych nie chciało nakładania kar na osoby uchylające się od tego obowiązku.

\section{Wnioski}

1. Poziom wiedzy rodziców na temat chorób zakaźnych i zasadności wykonywania szczepień ochronnych ulega pogorszeniu z uwagi na wpływ nierzetelnych źródeł informacji.

2. Ważnym źródłem wiedzy na temat szczepień ochronnych jest Internet, a w tym „fora społecznościowe", wypierające wiarygodność lekarzy - dlatego wskazana jest aktywność rzetelnych stron internetowych poświęconych wakcynologii.

3. Wskazane jest zintensyfikowanie i ukierunkowanie działań pracowników ochrony zdrowia odnośnie dysponowania rzetelną oraz wiarygodną wiedzą na temat szczepień ochronnych przekazywaną rodzicom.

\section{Piśmiennictwo}

1. Kałucka SK, Łopata E. Age-conditioned differences in parents' attitudes towards compulsory vaccination. Fam. Med. Prim. Care Rev. 2016; 18(4): 425-428.
2. Andrzejewska D. Odmowa szczepień ochronnych. Aspekty zdrowotne, etyczne i prawne. Mag. Pielęg. Położ. 2013; (9): 9-10.

3. Łopata E, Biesiada P, Kałucka S. Opinie rodziców na temat zasadności szczepień obowiązkowych w Polsce. Fam. Med. Prim. Care Rev. 2014; 16(3): 252-254.

4. Kiełducka A, Tarka P. Ruchy antyszczepionkowe, poziom wykształcenia rodziców a wykonywanie szczepień u dzieci. Zakażenia 2016; (3): 80-85.

5. Wróblewska I, Baran A, Sochocka L, Steciwko A. Analiza świadomości prozdrowotnej rodziców dzieci i młodzieży objętych Programem Szczepień Ochronnych. Fam. Med. Prim. Care Rev. 2011; 13(3): 530-535.

6. Gawlik K, Woś H, Waksmańska W, Łukasik R. Opinie rodziców na temat szczepień ochronnych u dzieci. Med. Og. Nauki Zdr. 2014; 20(4): 360-364.

7. Faleńczyk K, Piekarska M, Pluta A, Basińska H. Czynniki wpływające na postawy rodziców wobec szczepień ochronnych u dzieci. Post. Nauk Med. 2016; 29(6): 380-385.

8. Pieszka M, Waksmańska W, Woś H. Wiedza rodziców dzieci do drugiego roku życia na temat szczepień ochronnych. Med. Ogólna i Nauki o Zdrowiu 2016; 22(3): 221-226.

9. Kuchar E, Szenborn L. Postawy antyszczepionkowe i możliwości polemiki. Przew. Lek. 2010; (5): 43-46.

10. Rogalska J, Augustynowicz E, Gzyl A, Stefanoff P. Postawy rodziców wobec szczepień ochronnych w Polsce. Prz. Epidemiol. 2010; 64(1): 91-97.

11. Jaroszewska K, Marciniak A, Pawlak M, Życińska K, Wardyn K, Nitsch-Osuch A. Postrzeganie aktywności ruchów antyszczepionkowych przez rodziców małych dzieci. Post. Nauk Med. 2014; 27(9): 617-621.

12. Program Szczepień Ochronnych 2017 [przeglądany 08.03.2018]. Dostępny w: https://gis.gov.pl/images/ep/so/ pso_2017_-_nowelizacja.pdf.

13. Kochman D, Rudzińska T. Znaczenie edukacji rodziców w kontekście szczepień obowiązkowych i zalecanych u dzieci w wieku 0-2 lat. Probl. Pielęg. 2008; 16(1/2): 163-172.

14. Słopiecka A, Kwiecień E. Przyczyny negatywnych postaw ludności wobec szczepień. Hyg. Pub. Health 2014; 49(4): 685-689.

Artykuł przyjęty do redakcji: 23.09.2019.

Artykuł przyjęty do publikacji: 13.05.2020.

Źródło finansowania: brak. Konflikt interesów: nie zadeklarowano.

Adres do korespondencji:
Katarzyna Szymoniak
ul. Żołnierska 48
71-210 Szczecin
tel. 914800983 ; fax. 914800978
e-mail: katszym@pum.edu.pl
Samodzielna Pracownia Umiejętności Położniczych, Wydział
Nauk o Zdrowiu, Pomorski Uniwersytet Medyczny w Szczecinie

